\title{
The formation of pyrochlores during plasma spraying of reo and zirconia oxides powder mixture
}

Tadeusz KUBASZEK, Wojciech J. NOWAK, Paweł PĘDRAK, Marek GÓRAL, Kinga RYBUS, Karol ŚLEMP

DOI: 10.30464/jmee.2019.3.2.141

Cite this article as:

Kubaszek T., Nowak W. J., Pędrak P., Góral M., Rybus K., Ślemp K. The formation of pyrochlores during plasma spraying of reo and zirconia oxides powder mixture. Journal of Mechanical and Energy Engineering, Vol. 3(43), No. 2, 2019, pp. 141-148.

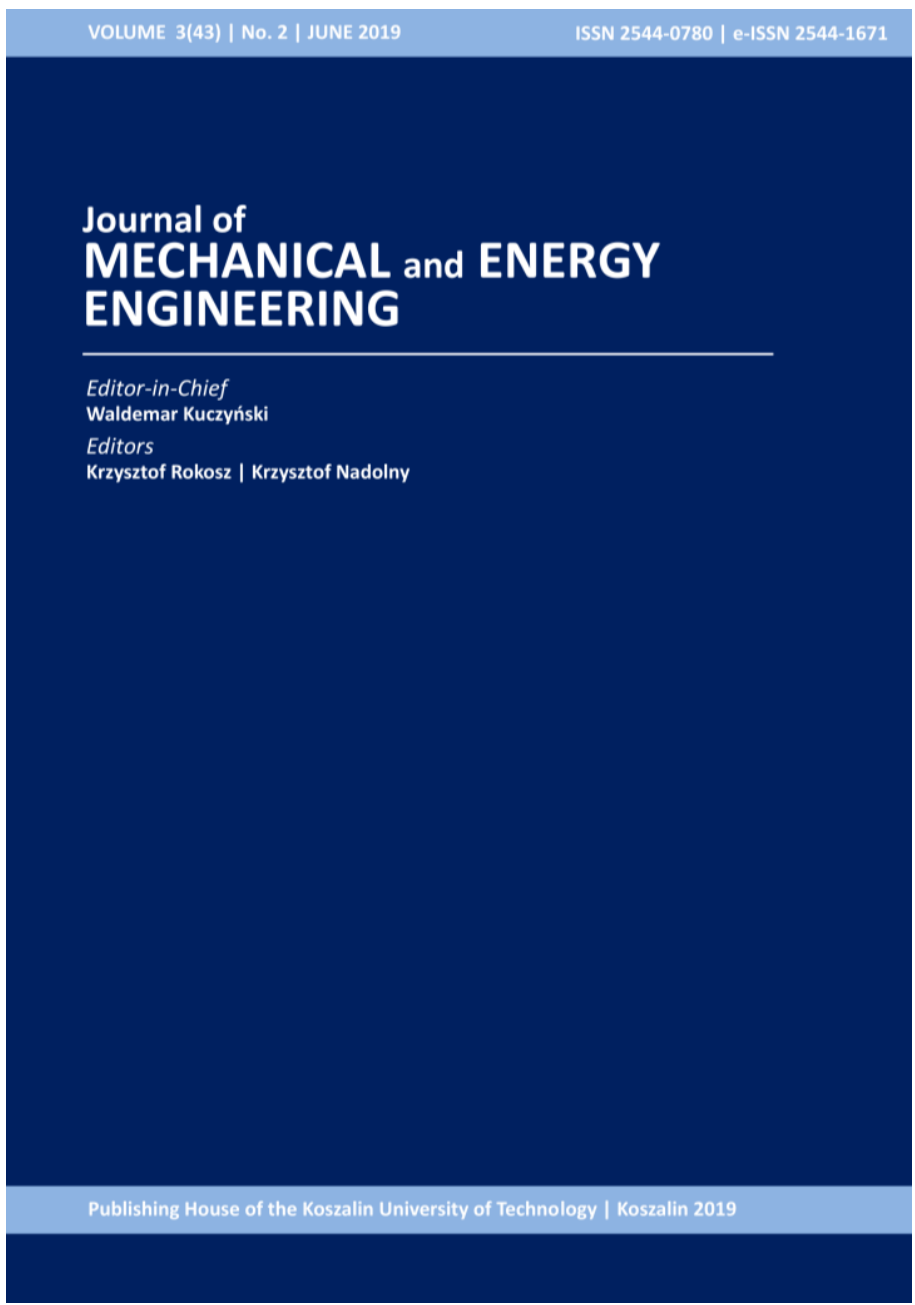

Journal of Mechanical and Energy Engineering

Website: jmee.tu.koszalin.pl

ISSN (Print): 2544-0780

ISSN (Online): 2544-1671

Volume: 3(43)

Number: 2

Year: 2019

Pages: 141-148

Article Info:

Received 27 May 2019

Accepted 2 June 2019

\section{Open Access}

This article is distributed under the terms of the Creative Commons Attribution 4.0 (CC BY 4.0) International License (http://creativecommons.org/licenses/by/4.0/), which permits unrestricted use, distribution, and reproduction in any medium, provided you give appropriate credit to the original author(s) and the source, provide a link to the Creative Commons license, and indicate if changes were made. 


\title{
THE FORMATION OF PYROCHLORES DURING PLASMA SPRAYING OF REO AND ZIRCONIA OXIDES POWDER MIXTURE
}

\author{
Tadeusz KUBASZEK ${ }^{2}$, Wojciech J. NOWAK ${ }^{2}$, Paweł PĘDRAK ${ }^{2}$, Marek GÓRAL $^{1 *}$, Kinga RYBUS ${ }^{2}$, \\ Karol ŚLEMP ${ }^{2}$ \\ ${ }^{1 *}$ Rzeszow University of Technology, Faculty of Mechanical Engineering and Aeronautic, \\ Department of Materials Science, Powstanców Warszawy 12, 35-959 Rzeszów, Poland, m_goral@interia.pl \\ ${ }^{2}$ Rzeszów University of Technology, Faculty of Mechanical Engineering and Aeronautic, \\ Department of Materials Science
}

(Received 27 May 2019, Accepted 2 June 2019)

\begin{abstract}
The pyrochlores are the promising low-thermal conductive materials for Thermal Barrier Coatings applications. In present work the concept of pyrochlore formation during APS spraying of $\mathrm{ZrO}_{2}$ and $\mathrm{ReO}$ was analyzed. The specially prepared agglomerated mixtures of $\mathrm{ZrO}_{2}$ with $\mathrm{Nd}_{2} \mathrm{O}_{3}, \mathrm{Yb}_{2} \mathrm{O}_{3}, \mathrm{Er}_{2} \mathrm{O}_{3}$ and $\mathrm{Gd}_{2} \mathrm{O}_{3}$ oxides were plasma sprayed using $\mathrm{A} 60$ plasma torch on NiCoCrAlY-type bond coat. The influence of plasma gasses composition on coatings' microstructure was investigated. The results of XRD phase analysis proved formation of pyrochlores from $\mathrm{Gd}_{2} \mathrm{O}_{3}+\mathrm{ZrO}_{2}$ and $\mathrm{Nd}_{2} \mathrm{O}_{3}+\mathrm{ZrO}_{2}$ mixtures. The formation of $\mathrm{Er}_{4} \mathrm{O}_{12} \mathrm{Zr}_{3}$ from $\mathrm{Er}_{2} \mathrm{O}_{3}+\mathrm{ZrO}_{2}$ mixture as well as $\mathrm{Zr}_{3} \mathrm{Yb}_{4}$ from $\mathrm{Yb}_{2} \mathrm{O}_{3}+\mathrm{ZrO}_{2}$ powder was detected. The presence of pure rare earth oxides (REO) and zirconia oxides was observed in all types of sprayed coatings. The microstructural assessment showed differences in porosity and thickness of obtained ceramic coatings depending of type of REO oxides. The analysis of results showed that it is possible to obtain pyrochlore ceramic coatings from pure oxides mixture. The plasma energy was not efficient for full formation of pyrochlores, therefore the presence of pure oxides was observed.
\end{abstract}

Keywords: Thermal Barrier Coatings, plasma spraying, ceramic coating, rare earth oxides, pyrochlores, porosity

\section{INTRODUCTION}

The increase of the turbine entry temperature of the turbine inlet temperature (TIT) determines the development of new materials used in construction of modern jet engines. The use of manufacturing process of turbine blades and vanes from nickel superalloys and modification of their chemical composition increased their heat stability [1]. At the same time, their resistance against high-temperature corrosion has decreased. Therefore, it is necessary to introduce heatresistant layers and coatings, which protect the substrate of the nickel superalloy. Particularly effective way of protecting the surface of components of the hot air section of a turbine aircraft engine is the use of thermal barrier coatings (TBCs). TBCs are always composed of at least two layers - the outer ceramic layer - most often zirconium oxide stabilized with
$\mathrm{ZrO}_{2} * \mathrm{nY}_{2} \mathrm{O}_{3}$ - YSZ (Yttria Stabilized Zirconia) - and an internal - MCrAlY type, metallic bond coat. Introduction of an outer ceramic layer enabled to effectively increase protection of the nickel superalloy substrate against the impact of the exhaust gas stream. In aerospace industry, thermal barrier coatings are produced primarily in the air plasma spray process (APS) [2]. Recently the development of thermal barrier coatings is oriented on using new ceramic materials characterized by lower thermal conductivity and higher working temperature [3]. The most promising materials are silicide, mulite and rare-earth oxides (REO) [4,5]. In recent time the research work is concerned on ceramic layers based on rare earth ziconates such as $\mathrm{Gd}_{2} \mathrm{Zr}_{2} \mathrm{O}_{7}$ [6], $\mathrm{Nd}_{2} \mathrm{Zr}_{2} \mathrm{O}_{7}$ [7], $\mathrm{Sm}_{2} \mathrm{Zr}_{2} \mathrm{O}_{7}$ [8]. This type of coatings is thermally sprayed using specially prepared ceramic powders. Those powders are produced by calcination of rareearth oxides with zirconia oxide and fractionation for using plasma-spraying process. [9-10]. In the present 
work the concept of formation REO zirconates during plasma spraying of $\mathrm{REO}$ and $\mathrm{ZrO}_{2}$ mixture was verified. The selection of those oxide components content in powder was oriented on formation of REO zirconates during thermal spray process.

\section{MATERIALS AND METHODS}

The stainless steel X2CrNiMo17-12-2-type was used as a base material for the TBC systems. A60 plasma torch (Thermico) was used for thermal spraying of bond coat as well as for ceramic layer of thermal barrier coating. The NiCoCrAlY bond coat was plasma sprayed using Amdry 386 powder (Oerlikon Metco) using process parameters presented in Table 1.

Tab. 1. The bond coat spraying parameters

\begin{tabular}{lc}
\hline Parameter & Value \\
\hline Powder feed rate, g/min & 10 \\
\hline Power current, A & 550 \\
\hline Ar flow rate, $\mathrm{dm}^{3} / \mathrm{min}$ & 70 \\
\hline Hydrogen flow rate, $\mathrm{dm}^{3} / \mathrm{min}$ & 4 \\
\hline
\end{tabular}

The ceramic powders were prepared by ball milling and agglomerating of pure $\mathrm{ZrO}_{2}$ and REO oxides. Their chemical composition was selected for easy formation of pyrochlore-type phases during plasma spray process. The chemical composition of used powers is presented in Table 2 .

Tab. 2 The chemical composition of powders used for plasma spraying

\begin{tabular}{|c|c|c|}
\hline $\begin{array}{c}\operatorname{Mixture} \operatorname{type}_{(\text {wt. \%) }}^{\mathrm{ZrO}_{2} \text { content }} \\
\end{array}$ & REO type & $\begin{array}{l}\text { REO content } \\
\text { (wt. \%) }\end{array}$ \\
\hline $\mathrm{Gd}_{2} \mathrm{O}_{3}+\mathrm{ZrO}_{2} 40$ & $\mathrm{Gd}_{2} \mathrm{O}_{3}$ & 60 \\
\hline $\mathrm{Er}_{2} \mathrm{O}_{3}+\mathrm{ZrO}_{2} 39$ & $\mathrm{Er}_{2} \mathrm{O}_{3}$ & 61 \\
\hline $\mathrm{Nd}_{2} \mathrm{O}_{3}+\mathrm{ZrO}_{2} 42.3$ & $\mathrm{Nd}_{2} \mathrm{O}_{3}$ & 57.7 \\
\hline $\mathrm{Yb}_{2} \mathrm{O}_{3}+\mathrm{ZrO}_{2} 61.5$ & $\mathrm{Yb}_{2} \mathrm{O}_{3}$ & 38.5 \\
\hline
\end{tabular}

To investigate the effect of plasma enthalpy on structure of ceramic coating the different compositions of $\mathrm{Ar} / \mathrm{H}_{2}$ ratio were used (Table 3). The other process parameters were constant: power current: 700A, powder feed rate: $10 \mathrm{~g} / \mathrm{min}$, plasma torch movement speed: $50 \mathrm{~mm} / \mathrm{s}$.

Tab. 2. Ceramic layer spraying parameters

\begin{tabular}{|c|c|c|}
\hline \multicolumn{2}{|c|}{$\begin{array}{l}\text { Plasma gasses flow rate, } \\
\mathrm{dm}^{3} / \mathrm{min}\end{array}$} & \multirow{2}{*}{$\begin{array}{c}\mathrm{Ar} / \mathrm{H}_{2} \\
\text { ratio }\end{array}$} \\
\hline $\mathrm{Ar}$ & $\mathrm{H}_{2}$ & \\
\hline 60 & 12 & $5: 1$ \\
\hline 48 & 12 & $4: 1$ \\
\hline 60 & 6 & $10: 1$ \\
\hline
\end{tabular}

Powders and coatings morphologies were investigated using scanning electron microscopy (SEM) Hitachi S3400N equipped with energy dispersive spectroscopy (EDS) detector. The thickness and porosity of coatings were measured on digital images using Aphelion 3.1. software. The phase analysis was conducted by X-ray Diffraction (XRD) using XTRa ARL diffractometer (Thermo Fisher). The obtained spectra were identified using ICDD database (International Centre For Diffraction Data).

\section{RESULTS AND DISCUSSION}

\subsection{Morphology of obtained ceramic powders}

The initial microscopic assessment showed that powders prepared by ball milling and mixing posses different morphology, which not permit them to be used for thermal spray process. The problems with powder feeding and blocking were previously observed. For thermal spraying technology special method of agglomeration of powders was developed, namely spray drying process with addition of special chemical additives was performed. The analysis of final powders morphology showed formation of agglomerated particles from equinoxed grains with size ranged from $100 \mathrm{~nm}$ to $2 \mu \mathrm{m}$ (Fig. 2 a-d)

\subsection{Roughness of coating}

The lowest roughness after thermal spraying was measured on surface of coatings formed from powder mixtures $\mathrm{Er}_{2} \mathrm{O}_{3}+\mathrm{ZrO}_{2}\left(\mathrm{R}_{\mathrm{a}}=6.66 \mu \mathrm{m}\right)$ and $\mathrm{Yb}_{2} \mathrm{O}_{3}+\mathrm{ZrO}_{2}$ $\left(\mathrm{R}_{\mathrm{a}}=6 \mu \mathrm{m}\right)$ (Fig 1). The highest roughness (over $\mathrm{R}_{\mathrm{a}}=15$ $\mu \mathrm{m})$ on surface of $\mathrm{Nd}_{2} \mathrm{O}_{3}+\mathrm{ZrO}_{2}$ plasma sprayed coating was measured. It was shown that this factor strongly depends of grain size as well as morphology of thermally sprayed powders.

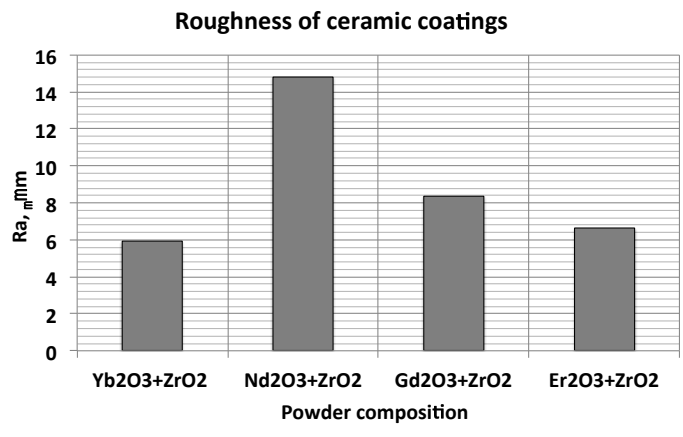

Fig. 1. Average roughness of plasma sprayed ceramic coating using different oxides mixture

3.3. Coatings sprayed using $\mathrm{Yb}_{2} \mathrm{O}_{3}+\mathrm{ZrO}_{2}$ powders The results of microscopic investigation showed that plasma gasses composition and flow rate strongly influence coating porosity and their thickness (Fig 3). It was shown that thickness of coatings sprayed using gas mixtures: $\mathrm{H}_{2}=6 \mathrm{dm}^{3} / \mathrm{min} \mathrm{Ar}=60 \mathrm{dm}^{3} / \mathrm{min}$ as well as $\mathrm{H}_{2}=12 \mathrm{dm}^{3} / \mathrm{min}$ and $\mathrm{Ar}=48 \mathrm{dm}^{3} / \mathrm{min}$ did not exceed $40 \mu \mathrm{m}$ (Fig. 3a). Thicker coating was formed when $\mathrm{H}_{2}=12 \mathrm{dm}^{3} / \mathrm{min}$ and $\mathrm{Ar}=60 \mathrm{dm}^{3}$ plasma gasses mixture was used. The increasing of hydrogen flow caused a reduction of coatings porosity from $35 \%$ to about $25 \%$.

The results of XRD phase analysis of thermally sprayed coating revealed the presence of oxides used for thermal spraying $\mathrm{Yb}_{2} \mathrm{O}_{3}$ and $\mathrm{ZrO}_{2}$ as well as $\mathrm{Zr}_{3} \mathrm{Yb}_{4}$ phase (Fig. 4). The REO pyrochlores were not detected. 
a)

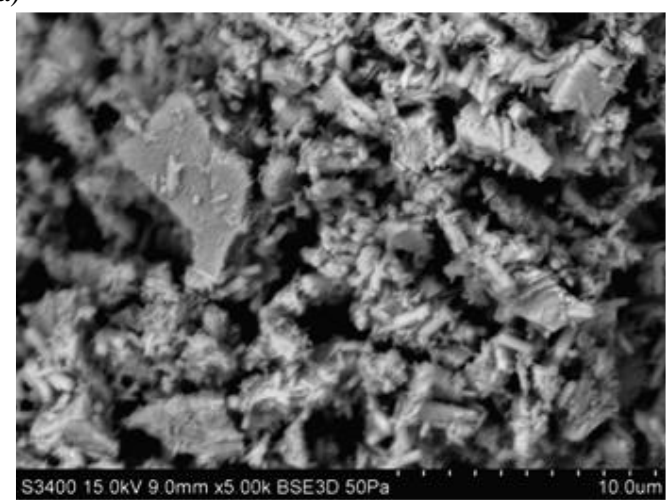

b)

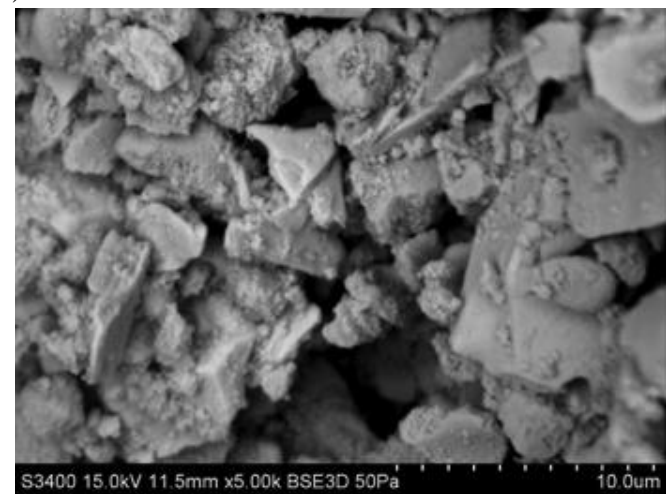

c)

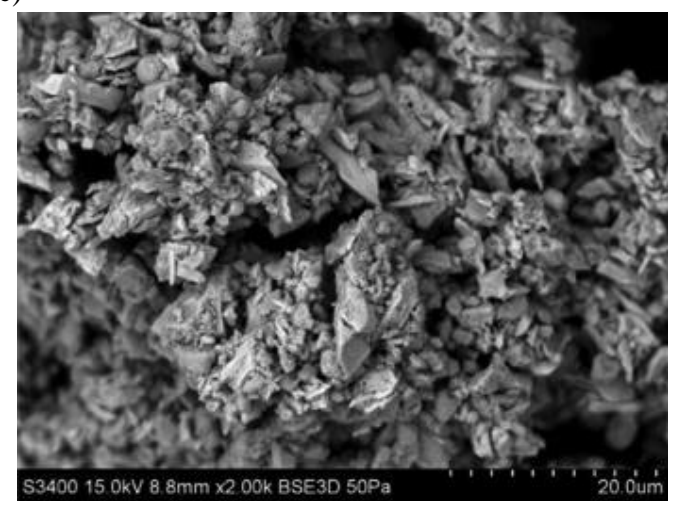

d)

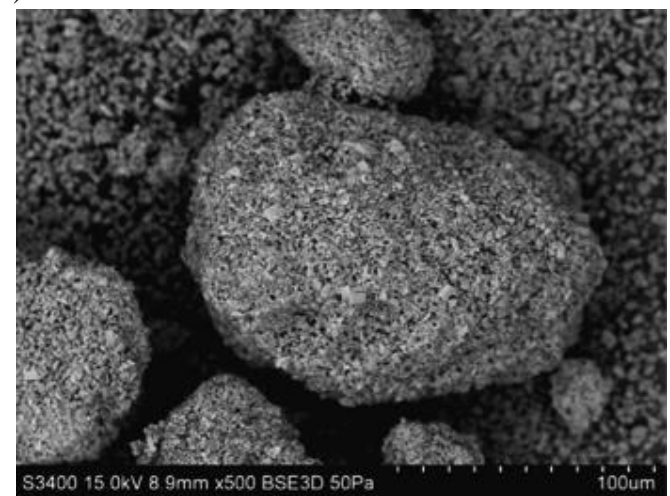

Fig. 2. Morphology of agglomerated powders used in experimental: a) $\mathrm{Gd}_{2} \mathrm{O}_{3}+\mathrm{ZrO}_{2}$ b) $\mathrm{Er}_{2} \mathrm{O}_{3}+\mathrm{ZrO}_{2}$, c) $\mathrm{Yb}_{2} \mathrm{O}_{3}+\mathrm{Zr}_{2} \mathrm{O}_{3}$, d) $\mathrm{Nd}_{2} \mathrm{O}_{3}+\mathrm{Zr}_{2} \mathrm{O}_{3}$ a)

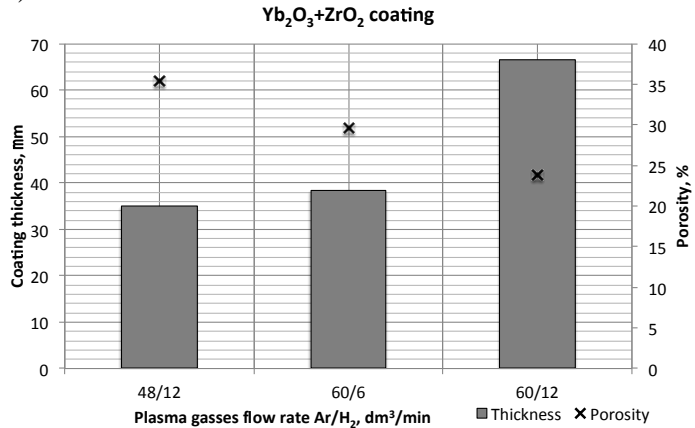

b)

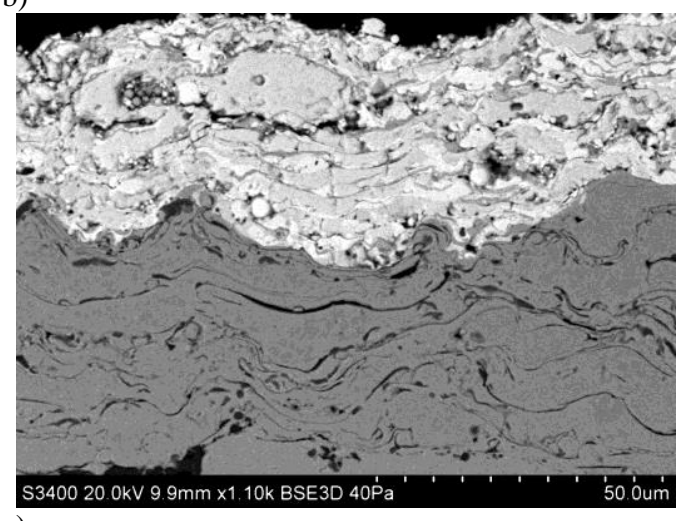
c)

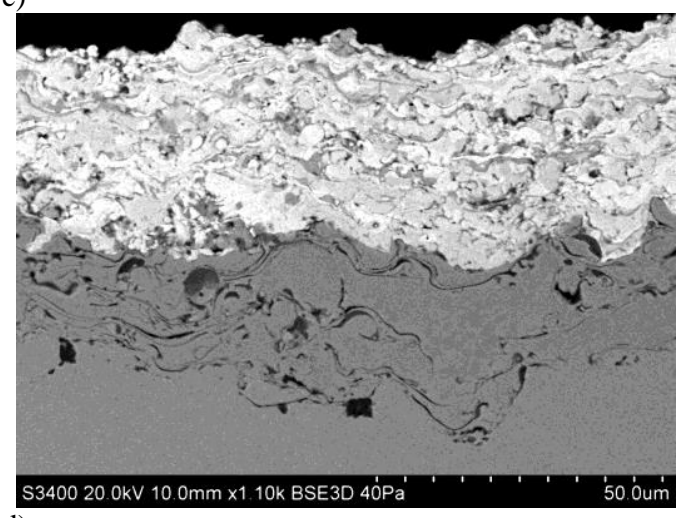

d)

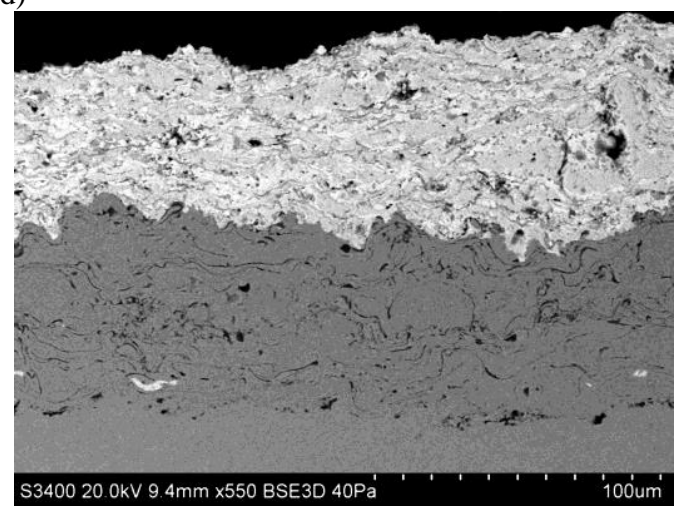

Fig. 3. The porosity and thickness (a) and microstructure of ceramic coatings formed by plasma spraying of $\mathrm{Yb}_{2} \mathrm{O}_{3}+\mathrm{ZrO}_{2}$ powder with plasma gasses flow: b) $\mathrm{H}_{2}=12 \mathrm{dm}^{3} / \mathrm{min}+\mathrm{Ar}=48 \mathrm{dm}^{3} / \mathrm{min} \mathrm{c}$ ) $\mathrm{H}_{2}=12$ $\mathrm{dm}^{3} / \mathrm{min}$ and $\mathrm{Ar}=60 \mathrm{dm}^{3} / \mathrm{min}$ and d) $\mathrm{H}_{2}=12 \mathrm{dm}^{3} / \mathrm{min}$ and $\mathrm{Ar}=60 \mathrm{dm}^{3}$ 


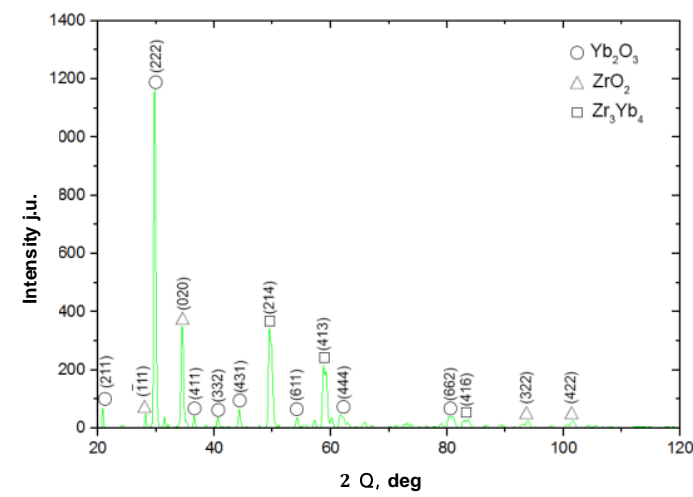

Fig. 4. XRD diffraction pattern from surface of ceramic layer plasma sprayed using $\mathrm{Yb}_{2} \mathrm{O}_{3}+\mathrm{ZrO}_{2}$ powders mixture and gas composition: $\mathrm{H}_{2}=12 \mathrm{dm}^{3} / \mathrm{min}$ and $\mathrm{Ar}=60 \mathrm{dm}^{3}$

\subsection{Coatings sprayed using $\mathrm{Nd}_{2} \mathrm{O}_{3}+\mathrm{ZrO}_{2}$ powder}

The using of higher hydrogen flow rate $\left(\mathrm{H}_{2}=12\right.$ $\mathrm{dm}^{3} / \mathrm{min}$ ) in plasma gasses mixture, independently of Ar flow enables to form thick coating (80-95 $\mu \mathrm{m})$ with lower porosity (about 30\%) (Fig. 5). If hydrogen flow rate was lower the obtained coating thickness was smaller than $70 \mu \mathrm{m}$ and their porosity was higher $(>45 \%)$.

The XRD phase analysis (Fig 6.) showed the presence of neodymium zirconate $\mathrm{Nd}_{2} \mathrm{Zr}_{2} \mathrm{O}_{7}$ as well as $\mathrm{Nd}_{1.85} \mathrm{Zr}_{0.1} \mathrm{O}_{3}$ phase. The zirconia oxide was also detected.

\subsection{Coatings sprayed using $\mathrm{Er}_{2} \mathrm{O}_{3}+\mathrm{ZrO}_{2}$ powders}

The ceramic coatings sprayed using $\mathrm{Er}_{2} \mathrm{O}_{3}+\mathrm{ZrO}_{2}$ powder and low plasma gasses flow $\left(\mathrm{H}_{2}=12 \mathrm{dm}^{3} / \mathrm{min}\right.$ and $\mathrm{Ar}=48 \mathrm{dm}^{3} / \mathrm{min}$ ) was characterized by lower porosity (about 25\%) and thickness (about $75 \mu \mathrm{m}$ ) (Fig. 9). The increase of overall plasma flow enabled to increase the coating thickness above $110 \mathrm{~mm}$. As a consequence the higher coating porosity (in range 30-35\%) was measured.

The phase composition analysis showed the presence of $\mathrm{Er}_{4} \mathrm{O}_{12} \mathrm{Zr}_{3}$ phase as well as components from plasma sprayed powder, namely erbium and zirconium oxides (Fig. 7).

\subsection{Coatings sprayed using $\mathrm{Gd}_{2} \mathrm{O}_{3}+\mathrm{ZrO}_{2}$ powders}

The using of higher overall plasma gasses flow $\left(\mathrm{H}_{2}=12 \mathrm{dm}^{3} / \mathrm{min}\right.$ and $\left.\mathrm{Ar}=60 \mathrm{dm}^{3}\right)$ enables to obtain the ceramic coating with the highest thickness $(>70 \mu \mathrm{m})$ and the lowest porosity $(25 \%)$ (Fig. 10). The decreasing of plasma gasses flow rate reduces the plasma enthalpy and as a result- decreases coatings thickness $(55-66 \mu \mathrm{m})$ and increases their porosity $(>45 \%)$ The XRD phase analysis showed the presence of gadolinium zirconate $\left(\mathrm{Gd}_{2} \mathrm{Zr}_{2} \mathrm{O}_{7}\right)$ as well as components of plasma sprayed powder $\left(\mathrm{ZrO}_{2}\right.$ and $\mathrm{Gd}_{2} \mathrm{O}_{3}$ ) (Fig. 8). a)

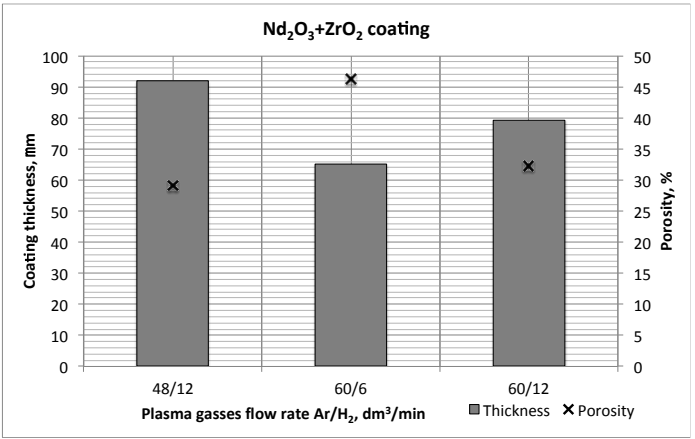

b)

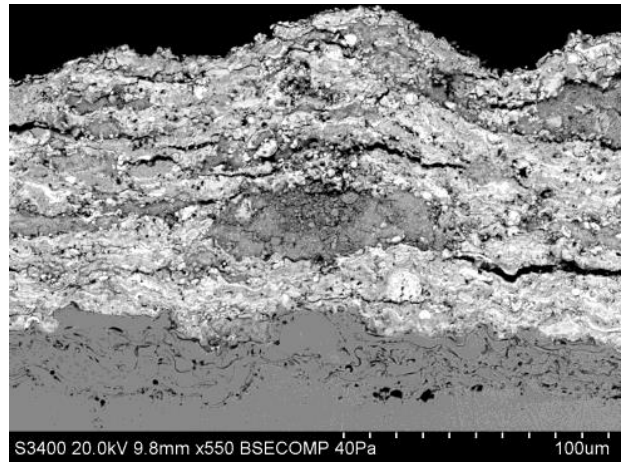

c)

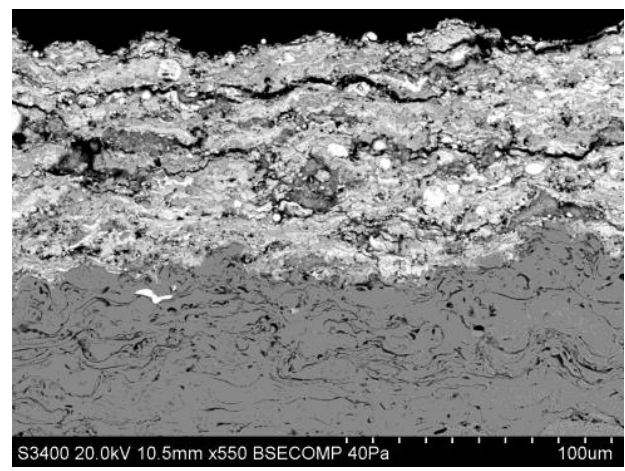

d)

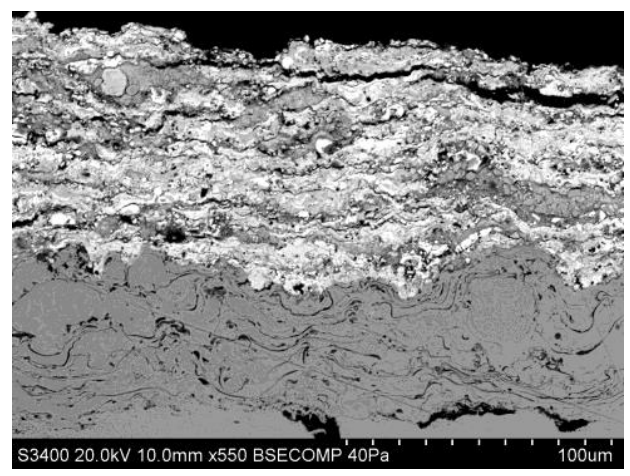

Fig. 5. The porosity and thickness (a) and microstructure of ceramic coatings formed by plasma spraying of $\mathrm{Nd}_{2} \mathrm{O}_{3}+\mathrm{ZrO}_{2}$ powder with plasma gasses flow: b) $\mathrm{H}_{2}=12 \mathrm{dm}^{3} / \mathrm{min}+\mathrm{Ar}=48 \mathrm{dm}^{3} / \mathrm{min}$ c) $\mathrm{H}_{2}=12 \mathrm{dm}^{3} / \mathrm{min}$ and $\mathrm{Ar}=60 \mathrm{dm}^{3} / \mathrm{min}$ and d) $\mathrm{H}_{2}=12 \mathrm{dm}^{3} / \mathrm{min}$ and $\mathrm{Ar}=60 \mathrm{dm}^{3}$ 


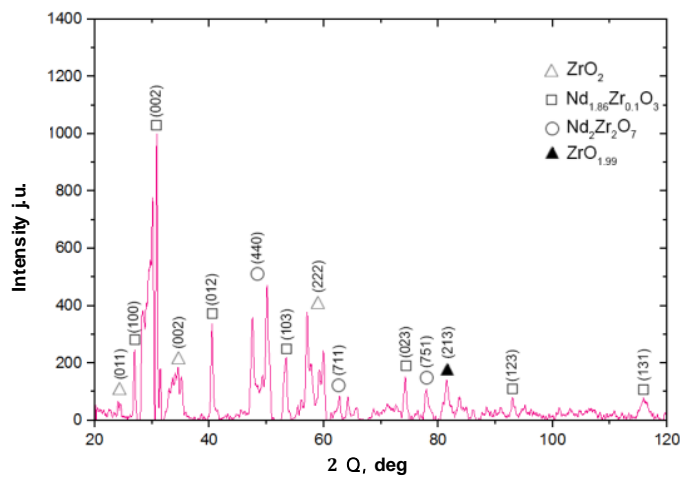

Fig. 6. XRD diffraction pattern from surface of ceramic layer plasma sprayed using $\mathrm{Nd}_{2} \mathrm{O}_{3}+\mathrm{ZrO}_{2}$ powders mixture and gas composition: $\mathrm{H}_{2}=12 \mathrm{dm}^{3} / \mathrm{min}$ and $\mathrm{Ar}=60 \mathrm{dm}^{3}$

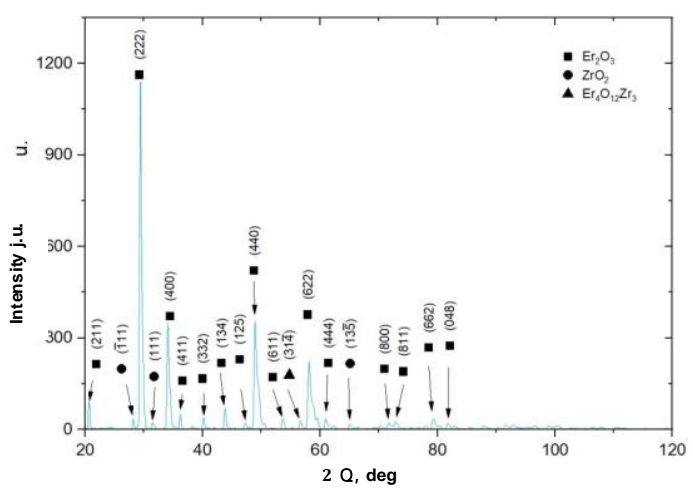

Fig. 7. XRD diffraction pattern from surface of ceramic layer plasma sprayed using $\mathrm{Er}_{2} \mathrm{O}_{3}+\mathrm{ZrO}_{2}$ powders mixture and gas composition: $\mathrm{H}_{2}=12 \mathrm{dm}^{3} / \mathrm{min}$ and $\mathrm{Ar}=60 \mathrm{dm}^{3}$

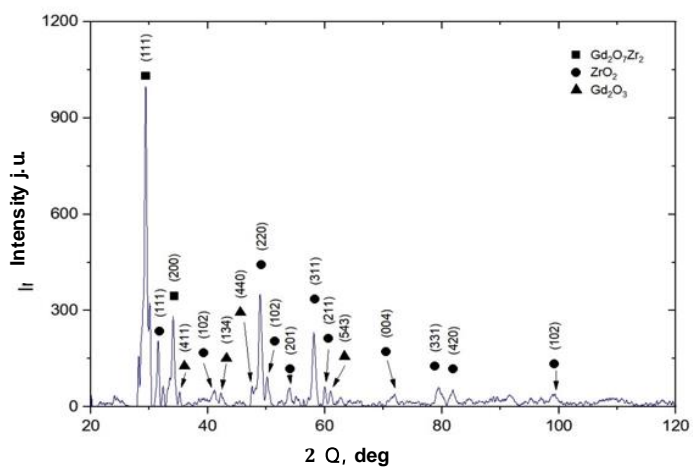

Fig. 8. XRD diffraction pattern from surface of ceramic layer plasma sprayed using $\mathrm{Gd}_{2} \mathrm{O}_{3}+\mathrm{ZrO}_{2}$ powders mixture and gas composition: $\mathrm{H}_{2}=12 \mathrm{dm}^{3} / \mathrm{min}$ and $\mathrm{Ar}=60 \mathrm{dm}^{3}$ a)

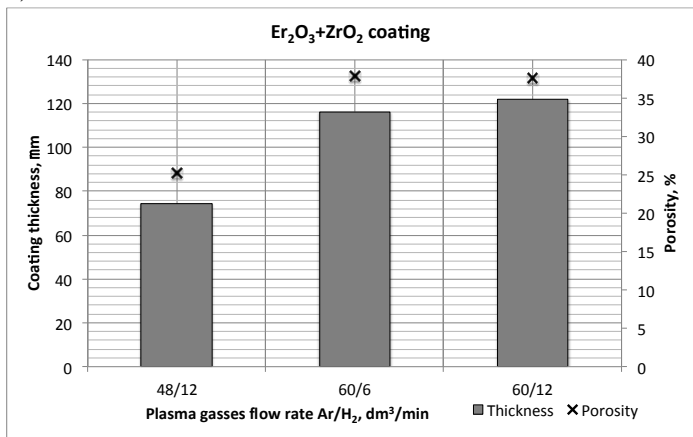

b)

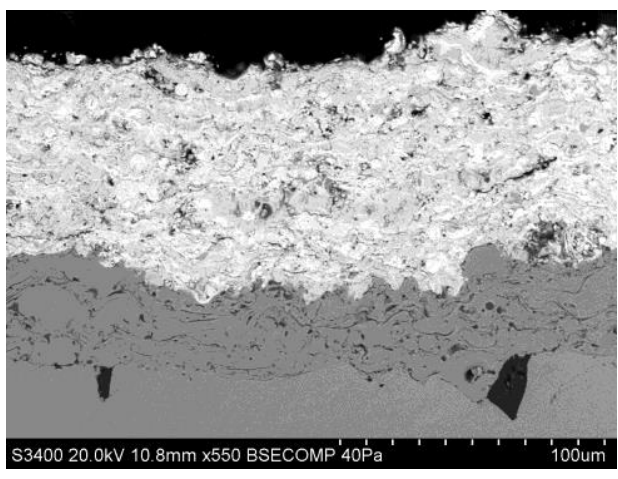

c)

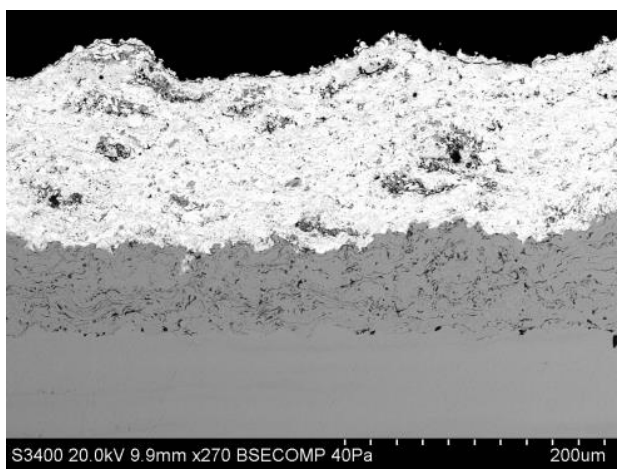

d)

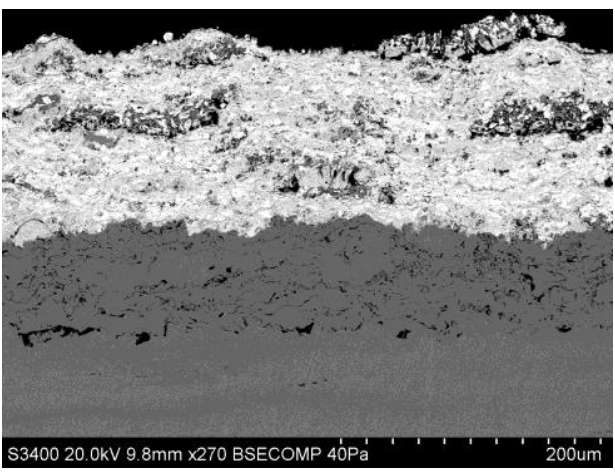

Fig. 9. The porosity and thickness (a) and microstructure of ceramic coatings formed by plasma spraying of $\mathrm{Er}_{2} \mathrm{O}_{3}+\mathrm{ZrO}_{2}$ powder with plasma gasses flow: $\mathrm{b}$ ) $\mathrm{H}_{2}=12 \mathrm{dm}^{3} / \mathrm{min}+\mathrm{Ar}=48 \mathrm{dm}^{3} / \mathrm{min}$ c) $\mathrm{H}_{2}=12 \mathrm{dm}^{3} / \mathrm{min}$ and $\mathrm{Ar}=60 \mathrm{dm}^{3} / \mathrm{min}$ and d) $\mathrm{H}_{2}=12 \mathrm{dm}^{3} / \mathrm{min}$ and $\mathrm{Ar}=60 \mathrm{dm}^{3}$ 
a)

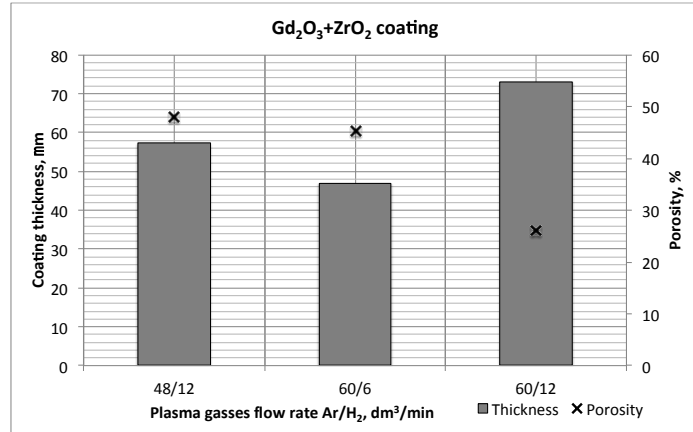

b)

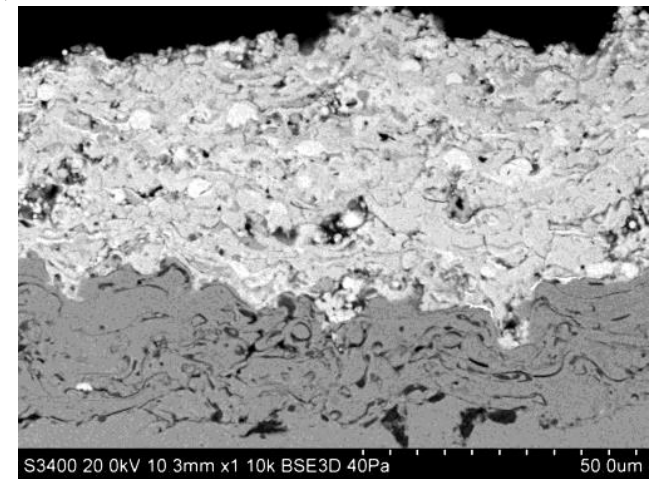

c)

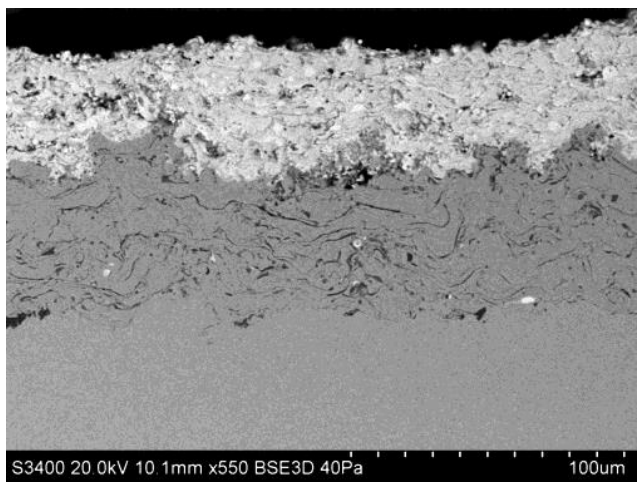

d)

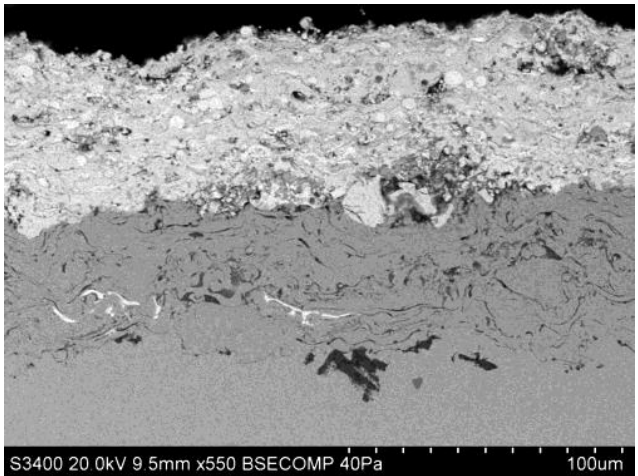

Fig. 10.The porosity and thickness (a) and microstructure of ceramic coatings formed by plasma spraying of $\mathrm{Gd}_{2} \mathrm{O}_{3}+\mathrm{ZrO}_{2}$ powder with plasma gasses flow: $\mathrm{b}$ ) $\mathrm{H}_{2}=12 \mathrm{dm}^{3} / \mathrm{min}+\mathrm{Ar}=48 \mathrm{dm}^{3} / \mathrm{min} \mathrm{c)} \mathrm{H}_{2}=12 \mathrm{dm}^{3} / \mathrm{min}$ and $\mathrm{Ar}=60 \mathrm{dm}^{3} / \mathrm{min}$ and d) $\mathrm{H}_{2}=12 \mathrm{dm}^{3} / \mathrm{min}$ and $\mathrm{Ar}=60 \mathrm{dm}^{3}$

\section{CONCLUSIONS}

The pyrochlores are the promising materials possessing low-thermal conductivity and can be used for Thermal Barrier Coatings application [6-10]. In conducted research concept of pyrochlore formation during APS spraying of $\mathrm{ZrO}_{2}$ and $\mathrm{REO}$ was analysed. The specially prepared agglomerated mixture of $\mathrm{ZrO}_{2}$ with $\mathrm{Nd}_{2} \mathrm{O}_{3}, \mathrm{Yb}_{2} \mathrm{O}_{3}, \mathrm{Er}_{2} \mathrm{O}_{3}$ and $\mathrm{Gd}_{2} \mathrm{O}_{3}$ oxides was plasma sprayed using A60 plasma torch on NiCoCrAlY-type bond coat. The influence of plasma gasses composition on coatings' microstructure was investigated. It was shown that increasing of overall plasma gasses flow as well as increasing of hydrogen flow rate leads to increase of plasma enthalpy. As a consequence of higher plasma energy, the thickness of ceramic coating was increased and the porosity was decreased.

The results of XRD phase analysis showed that plasma enthalpy had no influence of phase composition of obtained coatings. What is important, the pyrochlore $\mathrm{Nd}_{2} \mathrm{Zr}_{2} \mathrm{O}_{7}$ was formed during thermal spraying of $\mathrm{Nd}_{2} \mathrm{O}_{3}$ and $\mathrm{ZrO}_{2}$ oxides mixture. In this case the neodymium oxide formed pyrochlores and $\mathrm{Nd}_{1.86} \mathrm{Zr}_{0,1} \mathrm{O}_{3}$ phase. The partial transformation of gadolinium and zirconium oxide into $\mathrm{Gd}_{2} \mathrm{Zr}_{2} \mathrm{O}_{7}$ pyrochlore was observed. In the coating the pure oxides were present as well. During plasma spraying of ytterbium and zirconium oxide powders the $\mathrm{Zr}_{3} \mathrm{Yb}_{2}$ phase was formed. On the other hand the $\mathrm{Er}_{4} \mathrm{O}_{12} \mathrm{Zr}_{3}$ phase was synthetized during thermal spraying of $\mathrm{Er}_{2} \mathrm{O}_{3}$ and $\mathrm{ZrO}_{2}$ powders mixture.

The experimental results of thermal spraying processes showed that it is possible to obtain pyrochlore ceramic coatings from mixture of pure oxides. The plasma energy was not efficient to ful formation of pyrochlores so the presence of pure oxides and formation of other phases was observed. In further test the other plasma torches characterized by higher plasma enthalpy enables to form pyrochlores during thermal spraying is planned to be done to avoid an additional calcination process prior plasma spraying process.

\section{Acknowledgement}

Project co-financed by the European Regional Development Fund under the Operational Programme Innovative Economy and the National Centre for Research and Development Poland (NCBR) - Grant No. INNOLOT///7/NCBR/2013 - TED.

\section{References}

1. Drapier, J.M. Progress in advanced directionally solidified and eutectic high temperature alloys, Proceedings of Liege Conference, 1978

2. Nicoll, A.R., Gruner, H., Prince R., Wuest G., (1995) Thermal spray coatings for high temperature protection, Surface engineering, Issue 1. vol. 1, 59-71 
3. Pawlowski L., (2013), Strategic oxides for thermal spraying: problems of availability and evolution of prices, Surface and Coatings Technology, vol. 220, 14-19

4. Clarke D.R., Phillpot S.R., (2005) Thermal Barrier Coating Materials, Materials Today, volume 8, issue 6, 22-29

5. Vassen R., Jarligo M.O., Steinke T., Mack D.E., Strover D., (2010), Overview on advanced thermal barrier coatings, Surface and Coatings Technology, vol. 205 938-942

6. Moskal. G., (2011), Microstructure characterization of TBC layers of $\mathrm{Gd}_{2} \mathrm{Zr}_{2} \mathrm{O}_{7}$ type, Defect and Diffusion Forum, vol. 312-315 |439-444

7. Moskal, G., Swadźba, L., Hetmańczyk, M., Witala, B., Mendala, B., Mendala, J., Sosnowy, P., (2012) Characterisation of the microstructure and thermal properties of $\mathrm{Nd}_{2} \mathrm{Zr}_{2} \mathrm{O}_{7}$ and Ndassis $\mathrm{Zr}_{2} \mathrm{O}$ /YSZ thermal barrier coatings, Journal of the European Ceramic Society, vol. 32, issue 9, 2035-2042

8. Jucha, S., Moskal, G., Mikuśkiewicz, M., (2017), Morphology and durability of $\mathrm{Sm}_{2} \mathrm{Zr}_{2} \mathrm{O}_{7}+8 \mathrm{YSZ}$ TBC systems during oxidation test at temperature $1100^{\circ} \mathrm{C}$, Proceedings of the International Thermal Spray Conference, vol. 2 917-922

9. Jucha, S. Moskal, G., Mikuśkiewicz, M., (2016) Synthesis and characterization of thermal properties of type $\mathrm{Eu}_{2} \mathrm{O}_{3}-\mathrm{ZrO}_{2}$ sinters, Archives of Metallurgy and Materials, vol. 61 issue 2B, 1121-1128

10. Moskal, G., Iwaniak, A., Rozmysłowska-Grund, A. (2011), Characterization of thermal properties of microsized ceramic powders for APS deposition of ceramic layers, Key Engineering Materials, vol. 484 152-157

\section{Biographical Notes}

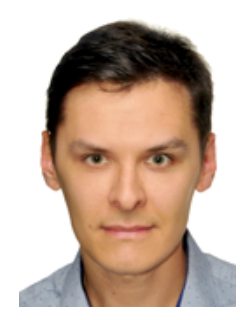

Tadeusz Kubaszek is a research assistant at Rzeszow University of Technology. He is specialized in atmospheric pressure plasma spray technologies. His scientific activity is connected with development of spraying techno-logy, coatings microstructure and properties and process diagnostic. He published over 20 publication in Polish and international journals.

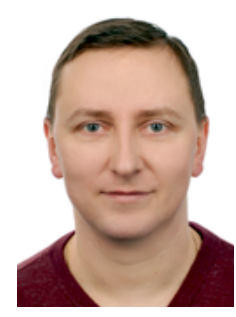

Wojciech J. Nowak is a assistant professor in Rzeszow University of Technology. He is specializes in high temperature corrosion analysis of materials and coatings especially thermal barrier coatings. Moreover, he is an expert in glow discharge optical emission spectrometry (GD-OES) analysis. He is an author of over 30 articles in international journals.

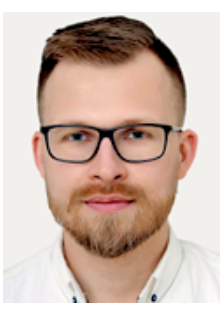

Pawel Pędrak is a research assistant at Rzeszow University of Technology. His research activity is connected with new ceramic materials for high temperature application. $\mathrm{He}$ is specialized in chemical and phase composition analysis of materials and coatings using XRF and XRD techniques. He is an author of about 10 articles in polish and international journal.

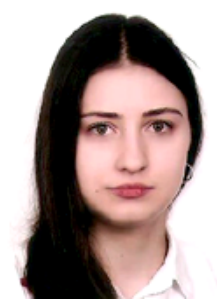

Kinga Rybus is a MSc student of materials science at Rzeszow University of Technology. Her research activity is connected with analysis of selected REO oxides and using them as a coating.

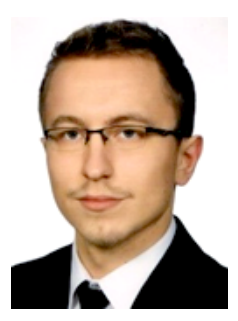

Karol Ślemp is a MSc student of materials science at Rzeszow University of Technology. His research activity is connected with analysis of selected REO oxides and using them as a coating.

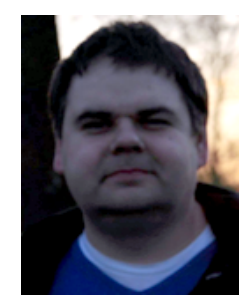

Marek Góral is a assistant professor at Rzeszow University of Technology. He is a specialized in high temperature protective coatings such as aluminides and thermal barrier coatings. In his area of activity is also thermal spray processes - especially low pressure plasma spraying (LPPS) and plasma spray physical vapour deposition (PSPVD). He is an author of over 40 articles in international journals. 
